\title{
HAEMOLYTIC FACTOR FROM BULL SEMINAL VESICLE FLUID: ISOLATION AND SOME PROPERTIES
}

\author{
С. KYSILKA \\ Czechoslovak Academy of Sciences, Laboratory of Animal Genetics, \\ Libèchov, Czechoslovakia
}

(Received 14th October 1971)

\begin{abstract}
Summary. Haemolytic factor, the protein responsible for the haemolysis of red blood cells, was isolated from bull seminal vesicle fluid. The purified protein has a mol. wt of 80,000 . Haemolytic factor dissociates in acidic urea buffer into sub-units with a mol. wt approximately ten times lower. Easy transitions in the sub-unit arrangement observed under various conditions are probably the reason for changes in electrophoretic mobility and in haemolytic activity.
\end{abstract}

\section{INTRODUCTION}

The investigation of individual protein components of the male genital fluids has not yet reached the extent that would correspond to its importance in the study of the reproductive physiology of animals.

One of the interesting components of the bull seminal plasma is the substance digesting erythrocyte ghosts designated as 'haemolytic factor' (HF). Millar (1956), who first detected the haemolytic effect of bull seminal plasma, found that the activity is perceptible at $\mathrm{pH} 4$ to 7 . This activity disappeared after freezing to $-20^{\circ} \mathrm{C}$ and subsequent thawing and it was also inactivated by temperatures higher than $56^{\circ} \mathrm{C}$. Bull seminal plasma shows haemolytic activity not only towards cattle red cells but also towards erythrocytes of other species (dog, horse, goat). The haemolytic effect is inhibited by blood serum. With respect to $\mathrm{HF}$ isolation, it is important to consider that the substance can be precipitated with ammonium sulphate and cannot be dialysed (Hunter, Stevens \& Hafs, 1963). Petrovský (1964) found that the sources of HF are the seminal vesicles and the ampullary fluids of bulls, but he studied this substance in its biological aspects only. The haemolytic capacity of bull seminal plasma was also described in the publications of Mitscherlich \& Paufler (1960), Romaniuk (1961), Molinary (1964), Fossum, Lyngset \& Aamdal (1965) and recently by Saison \& Kraay (1972).

The first attempts to isolate $\mathrm{HF}$ from bull seminal vesicle fluid were described by Matoušek (1969). In subsequent studies, the same author (Matoušek, 1970) differentiated three types of cattle erythrocytes according to their resistance towards HF. This resistance appears to be genetically determined. 
Finally, Matoušek \& Staněk (1970) investigated the effect of some enzymes, particularly those with proteolytic activity, on the stability and activity of HF. They confirmed the protein character of $\mathrm{HF}$ and obtained HF-rich fractions by ammonium sulphate precipitation and by gel filtration on Sephadex G-200.

\section{Seminal vesicle fluid}

\section{MATERIALS AND METHODS}

This was obtained from freshly slaughtered sexually mature bulls by gentle pressure on the excised glands after washing them in $0.9 \% \mathrm{NaCl}$.

The preparation of cattle erythrocyte suspensions and the haemolytic test

Cattle red blood cells were obtained from $5 \mathrm{ml}$ citrated blood by centrifuging ( $700 \mathrm{~g}$ for $5 \mathrm{~min}$ ) and suspending in $5 \mathrm{ml} \mathrm{0.9 \%} \mathrm{NaCl}$. After three such washings, a $2 \%$ suspension in $0.9 \% \mathrm{NaCl}$ was made immediately before use.

The haemolytic test was carried out and evaluated according to the method of Neimann-Sørensen (1958). For determination of activity in the fractions from columns stabilized with isotonic solutions, three drops from each fraction were collected and added to one drop of red blood cell suspension. Haemolytic activity was evaluated after 10,20 and $60 \mathrm{~min}$ incubation at $37^{\circ} \mathrm{C}$.

\section{Gels for column chromatography}

All types of Sephadex used in the experiments were supplied by Pharmacia, Uppsala, Sweden. The preparation of gels and the packing of columns were carried out according to manufacturer's directions.

\section{Electrophoretic methods}

Three methods were used. (a) Polyacrylamide gel electrophoresis (Ornstein \& Davis, 1964). Two types of gel were used: (i) basic ( $\mathrm{pH} \mathrm{9.4),7.5 \%} \mathrm{gel;}$ (ii) acidic ( $\mathrm{pH} \mathrm{4.3).} \mathrm{(b)} \mathrm{Starch} \mathrm{gel} \mathrm{electrophoresis} \mathrm{(Smithies,} \mathrm{1959).} \mathrm{Gels}$ $(20 \%)$ were made up with an acetic acid:formic acid buffer $(\mathrm{pH} 1.8)$ with and without $8 \mathrm{M}$-urea. The gel chambers measured $22 \times 11 \times 0.6 \mathrm{~cm}$ and were cooled with running water. Electrophoresis was carried out for $24 \mathrm{hr}$ at $380 \mathrm{~V}$ and $70 \mathrm{~mA}$. (c) Immunoelectrophoresis was performed as described by Scheidegger (1955), using $1 \%$ agar gel with $0.5 \mathrm{M}$-tris- $\mathrm{H}_{3} \mathrm{BO}_{3}$ buffer $(\mathrm{pH} 8.9)$. Rabbit antiserum against bull seminal vesicle fluid was used.

\section{Desalting}

Pooled fractions were desalted on Sephadex G-25 stabilized with 7 mM$\mathrm{NH}_{4} \mathrm{OH}$ after all column operations. The columns used for desalting measured $6 \times 75 \mathrm{~cm}$ or $4.5 \times 26 \mathrm{~cm}$, according to the quantity of material.

\section{Chemicals}

These were purchased from or imported by Lachema, Brno, Czechoslovakia.

\section{Preparation of starting material}

\section{RESULTS}

Seminal vesicle fluid of forty bulls (total volume, $100 \mathrm{ml}$ ) was diluted with 
$900 \mathrm{ml} 7 \mathrm{~mm}-\mathrm{NH}_{4} \mathrm{OH}$, desalted and freeze dried. This yielded $11.8 \mathrm{~g}$ of a high molecular weight fraction which was stored at $-20^{\circ} \mathrm{C}$. All the haemolytic activity was contained in this starting material.

\section{Isolation of haemolytic factor}

Two criteria were used for selecting material for further isolation: (1) higher titre of activity and (2) greater purity on disc electrophoresis than any fraction in the same or preceding isolation step. Purification procedures are shown in Text-fig. 1 and some disc electrophoretic patterns are shown in Text-fig. 3.

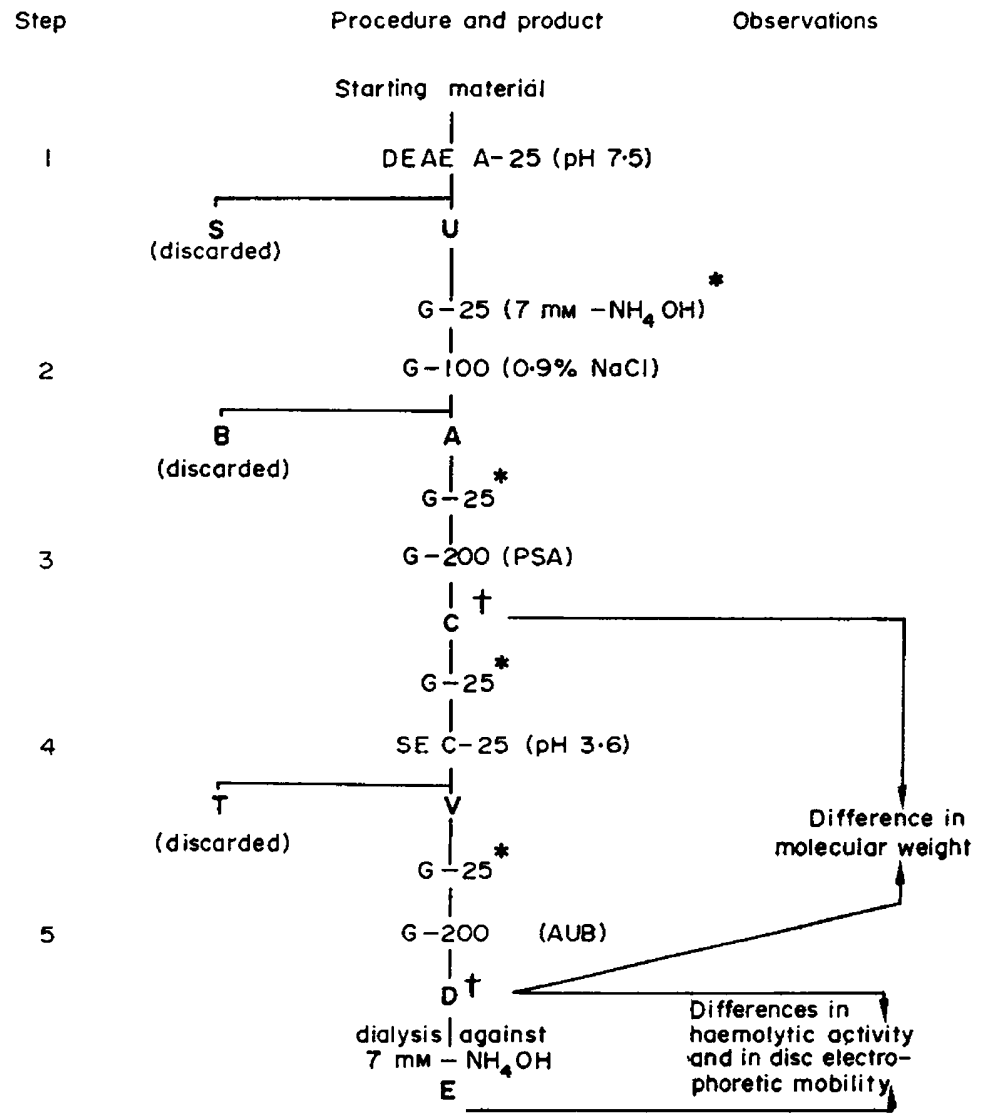

TexT-Fig. 1. Purification procedure for the isolation of haemolytic factor from bull seminal vesicle fluid. * Desalting procedure. $\dagger$ Used for molecular weight determination.

\section{Chromatography on DEAE Sephadex A-25 (Step 1)}

A 9.6-g quantity of the starting material was dissolved in $600 \mathrm{ml} 0.1 \mathrm{M}$-trisHCl buffer : $2 \mathrm{M}-\mathrm{NaCl}(\mathrm{pH} 7 \cdot 5)$. The sample was applied on a column $(39 \times 3 \mathrm{~cm})$ stabilized with the same buffer. After elution of non-attached proteins, the haemolytically active fraction was liberated with $8 \mathrm{~m}$-urea dissolved in the same buffer. The experiment yielded $2 \cdot 5 \mathrm{~g}$ active material (U, Text-fig. $2 \mathrm{a}$ ). 

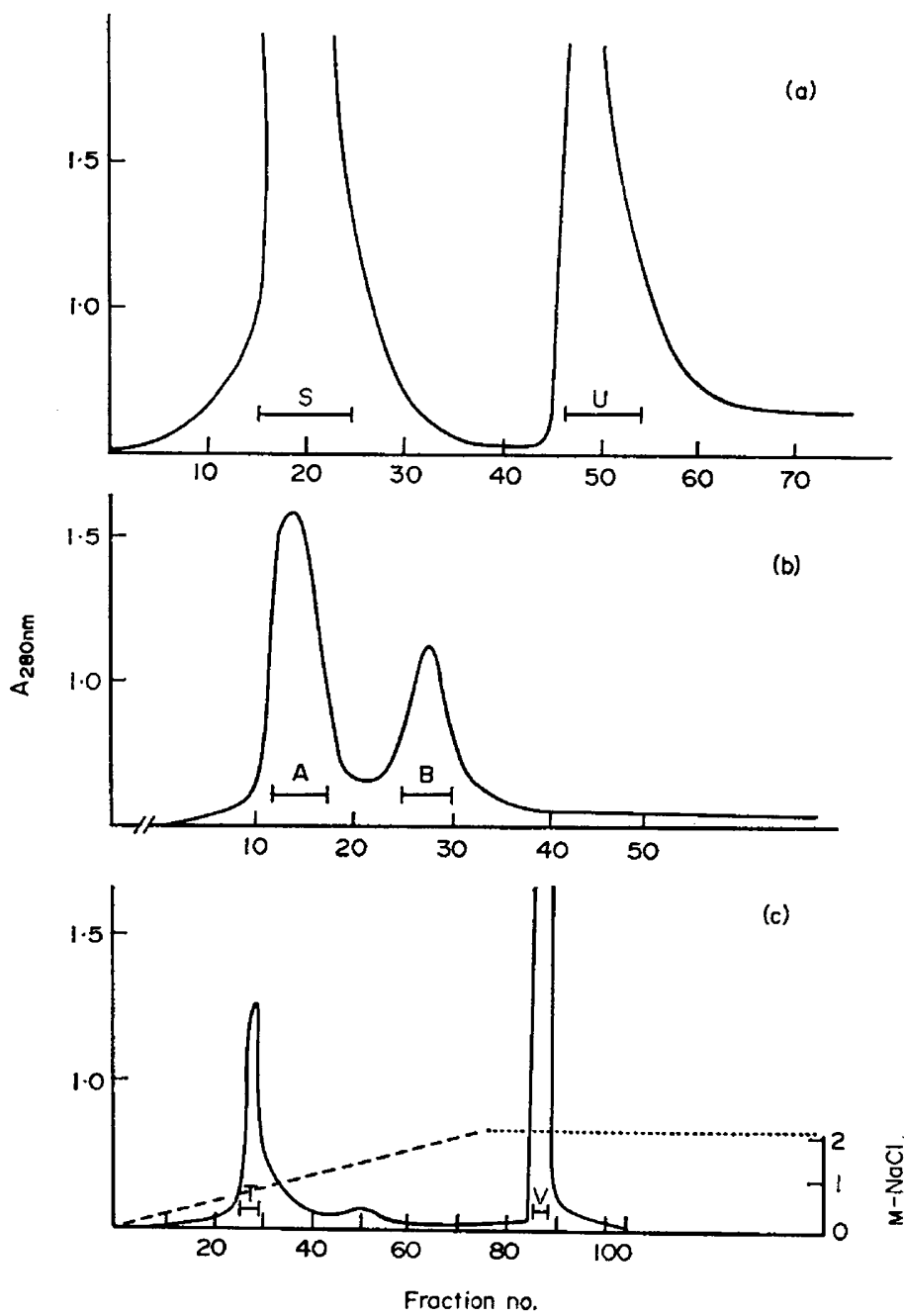

$\sum_{i}^{\overline{0}}$

TExT-FIG. 2. Elution patterns of some isolation steps in the purification of haemolytic factor from bull seminal vesicle fluid. (a) Two-step gradient elution on DEAE Sephadex A-25. Column $39 \times 3 \mathrm{~cm}$ stabilized with $0 \cdot 1 \mathrm{M}$-tris-HCl buffer: $2 \mathrm{M}-\mathrm{NaCl}$. Fractions collected: $20 \mathrm{ml} / 30 \mathrm{~min}$. (b) Gel filtration on Sephadex G-100. Column $52 \times 11 \mathrm{~cm}$ was stabilized with $0.9 \% \mathrm{NaCl}$. Fractions collected: $60 \mathrm{ml} / 30 \mathrm{~min}$. Haemolytic activity was detected in peak A. (c) Ghromatography on SE Sephadex G-25. Column $37 \times 3.2 \mathrm{~cm}$. Material $\mathrm{T}$ was eluted with $\mathrm{NaCl}$ gradient in $0.1 \mathrm{M}$-sodium acetate buffer, $\mathrm{pH} 3 \cdot 6$, material $\mathrm{V}$ with the final buffer with $8 \mathrm{~m}$-urea. Fractions collected: $10 \mathrm{ml} / 20 \mathrm{~min}$. Dashed line: concentration of $\mathrm{NaCl}$; dotted line: final buffer with 8 M-urea. 
Gel filtration on Sephadex $G$-100 (Step 2)

A 1.4-g quantity of desalted and freeze-dried material $U$ was dissolved in $100 \mathrm{ml} 0.9 \% \mathrm{NaCl}$ and fractionated on a Sephadex G-100 column $(52 \times 11 \mathrm{~cm})$. The material was divided into two peaks. Haemolytic activity was detected in Fraction A (Text-fig. 2b).

\section{Gel-filtration on Sephadex G-200 (Step 3)}

A 200-mg quantity of material A was purified on Sephadex G-200. The column $(81 \times 4 \mathrm{~cm})$, stabilized with $0.9 \% \mathrm{NaCl}$ dissolved in $0.7 \mathrm{~mm}-\mathrm{NH}_{4} \mathrm{OH}$ (PSA), was loaded with $20 \mathrm{ml}$ of $1 \%$ material A (Text-fig. 1) in the same solution. Both the activity and the protein content were revealed as a single peak (C) with a symmetrical profile. No traces of any other peak were detected. The peak $\mathrm{G}$ had a high haemolytic activity compared with the starting material.

Peak C gave the same disc-electrophoretic zones as material A. Material C was thus considered to be homogeneous by gel filtration. Part of this material was used for molecular weight determination after some necessary criteria of purity had been established (see below).

Ion-exchange chromatography on SE Sephadex C-25 (Step 4)

A $300-\mathrm{ml}$ column of SE Sephadex C-25 was stabilized with $0 \cdot 1$ M-sodium acetate buffer ( $\mathrm{pH} 3 \cdot 6)$. The sample ( $80 \mathrm{mg}$ of dried material $\mathrm{G}$ ) was dissolved in the same buffer and eluted from the column with a linear $\mathrm{NaCl}$ gradient ( 0 to $2 \mathrm{M}$ in the same buffer). In the range from 0.7 to $0.8 \mathrm{M}-\mathrm{NaCl}$, the nonsymmetrical peak $\mathrm{T}$ was liberated. A very sharp peak $\mathrm{V}$ (Text-fig. $2 \mathrm{c}$ ) was only eluted in the presence of $8 \mathrm{M}$-urea dissolved in the $2 \mathrm{M}-\mathrm{NaCl}$ final buffer.

Disc-electrophoretic patterns of both $\mathrm{T}$ and $\mathrm{V}$ were identical but the haemolytic activity of $\mathrm{V}$ was higher and this was chosen for further experiments.

\section{Chromatography on Sephadex G-200 in urea (Step 5)}

Material V, $33 \mathrm{mg}$ dissolved in $2 \mathrm{ml}$ of acidic urea buffer (AUB, i.e. $8 \mathrm{~m}$-urea in $0.1 \mathrm{M}$-sodium acetate buffer, $\mathrm{pH} 3.6)$ was placed on a column $(27 \times 2 \mathrm{~cm})$ of Sephadex G-200 stabilized with the same solution. Gel filtration yielded only a very sharp peak $\mathrm{D}$ containing the most active material so far isolated.

The whole fraction $\mathrm{D}$ was dialysed against several portions of ice-cold $7 \mathrm{~mm}-\mathrm{NH}_{4} \mathrm{OH}$. After freeze drying, material $\mathrm{E}$ was obtained. By comparing materials $\mathrm{D}$ and $\mathrm{E}$, it was found that $\mathrm{E}$ had a lower activity than $\mathrm{D}$.

The increase in haemolytic activity after the above isolation procedure and its rapid decrease after the last operation are evident from Table 1.

\section{Structural changes observed}

As shown in Text-fig. 3, materials $\mathrm{D}$ and $\mathrm{E}$ changed their zone intensities without formation or removal of a zone. These differences were coupled with considerable changes in haemolytic activity. In further experiments employing various volatile buffers, it was observed that the $\mathrm{pH}$ of the HF solution used for freeze-drying had a great influence on electrophoretic mobility. The same phenomenon was seen after desalting material C on Sephadex G-25 in basic or acidic solution ( $7 \mathrm{~mm}-\mathrm{NH}_{4} \mathrm{OH}$ and $2 \%$ acetic acid, respectively). 
The results described above led to the comparison of elution volumes, both of active material C (on Sephadex G-200 in PSA and in AUB) and human serum albumin (mol. wt 69,000) which served as a standard. In PSA, the elution volumes of these two proteins were nearly the same. In AUB, on the other hand, considerable differences were found: material $\mathrm{C}$ had an elution volume corresponding to about one ninth that of human serum albumin. The sample was eluted in one peak and no trace of any other peak was seen. All

Table 1. Haemolytic activity of bull seminal vesicle fluid and the final products of purification

\begin{tabular}{c|c|c|c}
\hline $\begin{array}{c}\text { Time of } \\
\text { incubation } \\
(\text { min })\end{array}$ & \multicolumn{2}{|c}{$\begin{array}{c}\text { Titre of total haemolysis } \\
\text { for materials }(1 \% \text { solution } \\
\text { in } P S A)\end{array}$} \\
\cline { 2 - 4 } & $S M$ & $D$ & $E$ \\
\hline 10 & 1 & 64 & 4 \\
20 & 2 & 64 & 16 \\
60 & 2 & 64 & 16 \\
\hline
\end{tabular}

For abbreviations, see text. Activity was measured at 10-, 20- and 60-min intervals. The HF titre given is that of the last tube showing total haemolysis. SM = Starting material.
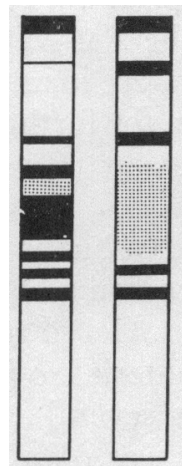

SM

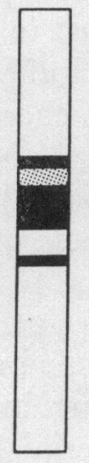

U

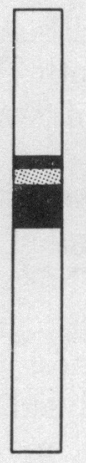

C

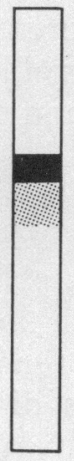

D

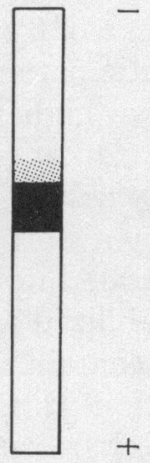

E

TExT-FIG. 3. Disc-electrophoresis after some isolation steps in the purification of haemolytic factor from bull seminal vesicle fluid. The lettering of the materials corresponds to the text.' Running gel pH: 9·4. Diffused zones are given by dotted areas.

material was converted to the lower molecular weight form. The results obtained suggest a sub-unit structure of the HF and led to direct determination of molecular weight.

\section{Criteria of purity of material $C$}

Starch gel electrophoretic mobilities of the starting material and material $\mathrm{C}$ were compared in an acidic gel with and without $8 \mathrm{M}$-urea. In the acetic 


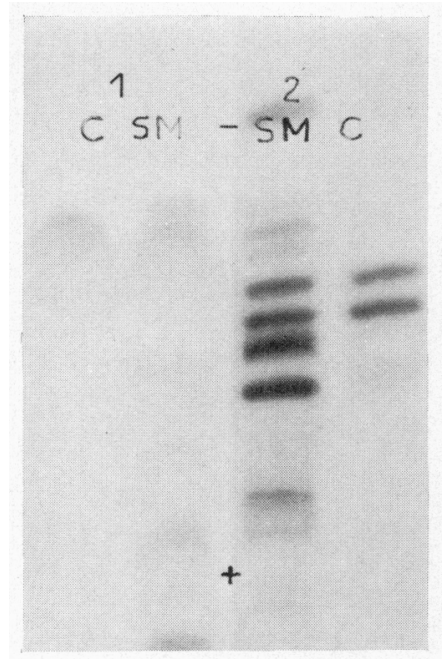

FIG. I

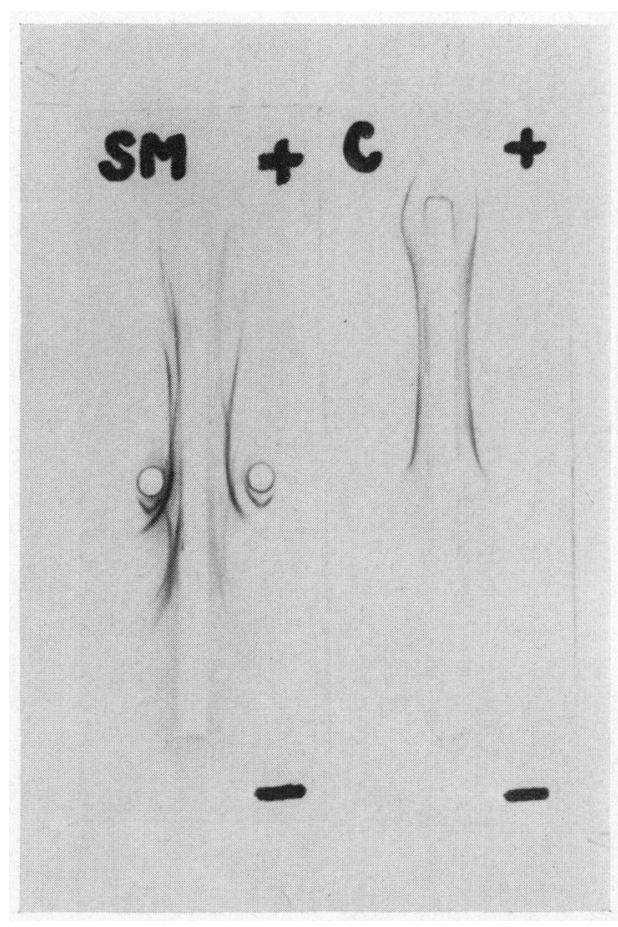

Fig. 2

FIG. 1. Starch-gel electrophoretic comparison of the starting material SM from bull seminal vesicle fluid with purification material $\mathrm{C}$. (1) Gel in buffer $\mathrm{pH} 1.8$ without urea. (2) Gel with 8 m-urea. The starting material served for the comparison. $20 \%$ gels, $10 \%$ solutions of samples in gel buffers, 24-hr run at $280 \mathrm{~V}$ and $70 \mathrm{~mA}$.

Frg. 2. Immunoelectrophoretic comparison of purification material $\mathrm{C}$ and the starting material SM from bull seminal vesicle fluid. Rabbit antiserum against seminal vesicle fluid of bulls, $0.5 \mathrm{M}$-tris- $\mathrm{H}_{3} \mathrm{BO}_{3}$ buffer, $\mathrm{pH} 8 \cdot 9$.

(Facing p. 190) 
acid:formic acid buffer, only one distinct zone was detected. In the presence of $8 \mathrm{M}$-urea in this buffer, two zones were revealed (Pl. 1, Fig. 1).

The precipitation arc on immunoelectrophoresis of material $\mathrm{G}$ was immunologically homogeneous. Its elongated shape corresponded to the diffusion shown in starch gel and disc electrophoretic zones (Pl. 1, Fig. 2).

Molecular weight determination on Sephadex G-200

Two similar columns of Sephadex G-200 were used. One was stabilized with PSA, the other with AUB. The sample/gel volume ratio was constant (1/100). Standards and material $\mathrm{C}$ were applied as $1 \%$ solutions in the appropriate running fluids.

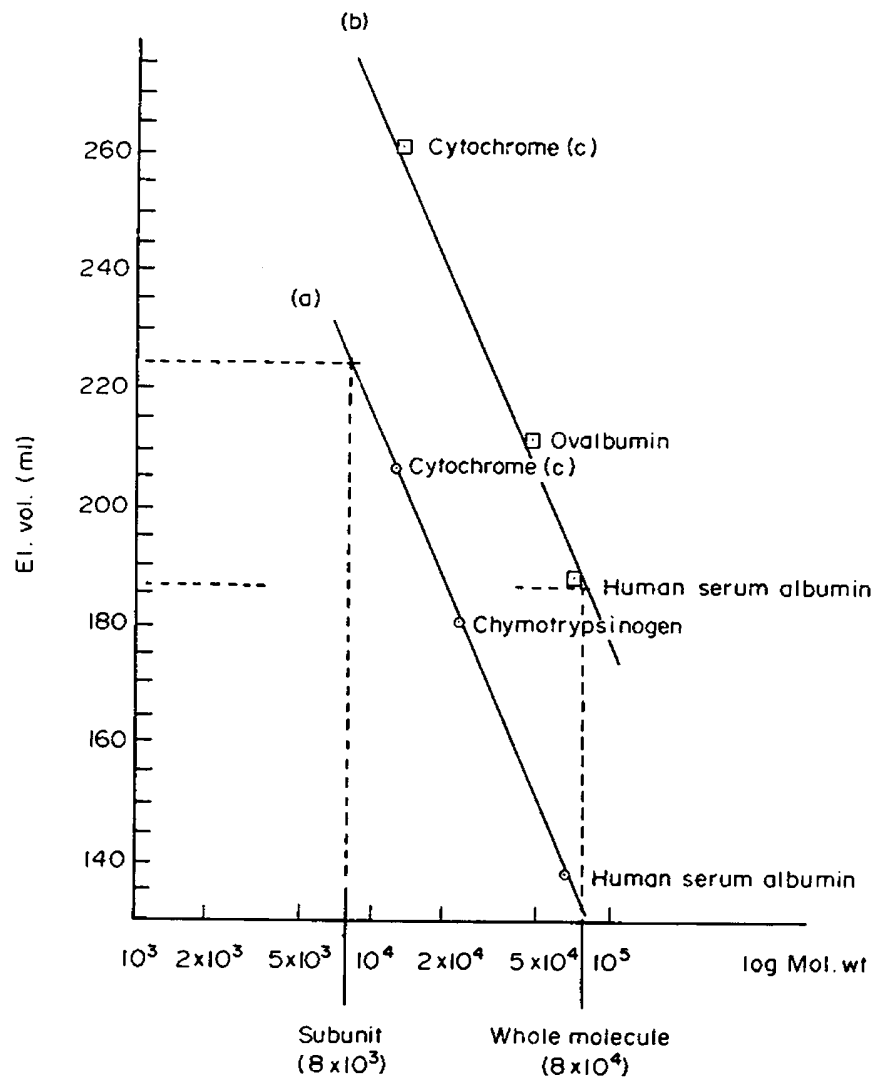

TEXT-F1G. 4. Molecular weight determination on Sephadex G-200 of haemolytic factor in bull seminal vesicle fiuid. (a) In acidic urea buffer. Column $37 \times 3.2 \mathrm{~cm}$. (b) $0.9 \%$ $\mathrm{NaCl}$ in $0.7 \mathrm{~mm} \mathrm{NH} 4 \mathrm{OH}$. Column $39 \times 3.2 \mathrm{~cm}$. Fractions collected: $4 \mathrm{ml} / 15 \mathrm{~min}$.

Text-figure 4 shows that the molecular weight in PSA was approximately 80,000 , but in AUB it was only about 8000 . The results obtained confirm the sub-unit structure of the HF molecule.

\section{DISGUSSION}

Total purification of either the high or low molecular weight forms of HF may 
be hindered by easy transition between the two forms. The mechanism of association and dissociation is so far unknown. Both $\mathrm{pH}$ and urea appear to play a part. Studies using starch gel electrophoresis indicate that urea is necessary for decomposition of the original molecule into sub-units. The two zones in starch gel could be various stages of aggregation, ionization forms of the sub-unit or, finally, different sub-units.

End-group analysis will be an important aid in further study of this problem. Attempts at reactivation of material $\mathrm{E}$ under various conditions will also be important. The mechanism and kinetics of the haemolysis itself require investigation. It would be interesting to show which component of the membrane is damaged by the haemolytic factor. The final result of this work might help towards the elucidation of haemolytic factor function in reproduction.

\section{ACKNOWLEDGMENTS}

The author wishes to express thanks to Dr J. C. Boursnell of the A.R.G. Unit of Reproductive Physiology and Biochemistry, Cambridge, Great Britain, for his helpful criticism during the preparation of this manuscript. He is indebted to Mrs Ing. A. Hellichová for her excellent assistance.

\section{REFERENCES}

Fossum, K., Lyngset, O. \& Aamdal, J. (1965) Quantitative determination of proteolytic, lipolytic and haemolytic activities in semen of some animal species. Acta vet. scand. $6,318$.

Hunter, A. G., Stevens, K. R. \& Hafs, H. D. (1963) Characteristics of the hemolytic factor in bovine seminal plasma. 7. Dairy Sci. 46, 618.

Matoušer, J. (1969) Antigenicity of the seminal vesicle fuid of bulls. In: Proc. Symp. on Immunology of Spermatozoa and Fertilization, held in Varna, Bulgaria, 1967, p. 135. Ed. K. Bratanov. Bulgarian Academy of Sciences Press, Sofia.

MATOUŠEK, J. (1970) Haemolytic factor in bovine seminal vesicle fluid. I. Individual differences in the sensitivity of cattle erythrocytes. Anim. Blood Groups \& biochem. Genet. 1, 89.

MAtoušek, J. \& STANĚx, R. (1970) Haemolytic factor in bovine seminal vesicle fluid. II. First attempt at fractionation and enzymatic splitting. Anim. Blood Groups $\mathbb{E}$ biochem. Genet. 1, 157.

Millar, P. G. (1956) Observations on the presence of a haemolysin in bovine semen. Br. vet. F. 112, 106.

Mrtscherlich, E. \& Paufler, S. (1960) Ueber eine hämolysierende Substanz in Bullensamen. Dt. tierärztl. Wschr. 67, 614 .

Molinary, G. (1964) A haemolytic substance in bull semen. Atti Soc. ital. Sci. vet. 17, 383.

Neimann-Sørensen, A. (1958) The hemolytic test for blood typing. In: Blood Groups of Cattle, p. 35. C. Mortensen, Copenhagen.

Ornstein, L. \& Davis, B. J. (1964) Disc electrophoresis. Ann. N.X. Acad. Sci. 121, 366.

Petrovský, E. (1964) Hemolytická aktivita semenné plazmy býků a kancủ a jeji vztah k chladovému šoku spermií. Sb. ¿sl. Akad. zeméd. Vyd, E. 9, 405.

Romaniuk, J. (1961) Occurrence of haemolytic factor in bull semen plasma. Zesz. probl. Postęp. Aauk roln. 31, 183.

SAISON, R. \& KrAAY, G. J. (1972) A non-specific inhibiting factor in the seminal plasma of bulls. In: Proc. XIIth Int. Conf. on Anim. Blood Grps and Biochem. Polymorphism, held in Budapest, 1970, p. 233. Eds. G. Kovács and M. Papp. Akadémiai Kiadó, Budapest.

Scheidegger, J. J. (1955) Une micro-méthode de l'immunoélectrophorèse. Int. Archs Allergy appl. Immun. 7, 103.

Smithies, O. (1959) Zone electrophoresis in starch gel and its application to studies of serum proteins. Adv. Protein Chem. 14, 65. 